\title{
Role of red blood cell scintigraphy for determining the localization of gastrointestinal bleeding
}

\author{
Gastrointestinal kanama odağının saptanmasında işaretli eritrosit sintigrafisinin rolü
}

\author{
Yasemin ŞANLI, ${ }^{1}$ Zeynep Gözde ÖZKAN, ${ }^{1}$ Serkan KUYUMCU, ${ }^{1}$ Hakan YANAR, ${ }^{2}$ Emre BALIK, ${ }^{2}$ \\ Handan TOKMAK, ${ }^{1}$ Cüneyt TÜRKMEN, ${ }^{1}$ Işık ADALET ${ }^{1}$
}

\section{BACKGROUND}

We aimed to evaluate the role of Tc-99m labeled red blood cell (RBC) scintigraphy for determination of localization of gastrointestinal system (GIS) bleeding.

\section{METHODS}

Fifty-seven cases (27 females, 30 males; mean age $43.9 \pm 24$; range 1 to 91 years) who referred to our clinic between 1995-2010 were evaluated for determination of localization of GIS bleeding with RBC scintigraphy. Prior to scintigraphy, gastroscopy in 51, colonoscopy in 45 , and angiography in 9 patients were performed.

\section{RESULTS}

RBC scintigraphies were positive and negative in 31 and 26 patients, respectively. Positive scintigraphic findings were obtained within the 1st hour of dynamic imaging in 19 patients, within the 1 st-4th hour static images in 7, and within the 4th-24th hour images in 5 patients. Fourteen patients underwent surgical exploration. In 13 patients, the surgery confirmed the diagnosis by RBC scintigraphy (accuracy: 92.8\%). Of 43 patients without surgical exploration, 12 had anemia due to iron deficiency and their scintigraphic evaluation were negative. Four patients died and in 27 patients, GIS bleeding ceased spontaneously or with conservative measures.

\section{CONCLUSION}

Scintigraphy should be the primary tool for accurate diagnosis of patients with active GIS bleeding. Positive dynamic images obtained within the first hour of imaging may be more accurate for demonstrating bleeding localization and a good predictor of requirement of surgical exploration.

Key Words: Gastrointestinal bleeding; red blood cell scintigraphy; endoscopic intervention.

\begin{abstract}
AMAC
Gastrointestinal sistem (GIS) kanamalarında kanama odağ1nın saptanmasında, Tc-99m ile işaretli eritrosit (RBC) sintigrafisinin rolü klinik deneyimlerimiz ışığında değerlendirildi.
\end{abstract}

\section{GEREÇ VE YÖNTEM}

1995-2010 yılları arasında GİS kanaması odağının belirlenmesi amaciyla kliniğimize gönderilen 57 hasta (27 ka-

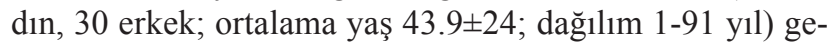
riye dönük olarak çalışmaya alındı. Sintigrafi öncesi hastaların 51'ine gastroskopi, 45'ine kolonoskopi, 9'una anjiyografi yapılmıştı.

\section{BULGULAR}

RBC sintigrafisi hastaların 31 'inde pozitif ve 26'sında negatifti. Pozitif sintigrafik bulgular, 19 hastada ilk bir saatlik dinamik imajlarda, 7 hastada 1-4. saatler arası statik imajlarda, 5 hastada ise 4-24. saatler arasında alınan statik imajlarda kaydedildi. Toplam 14 hasta GİS kanaması nedeniyle ameliyat edildi. On üç hastada kanama yeri RBC sintigrafisi tanısıyla doğrulandı (doğruluk: \%92,8). Ameliyat edilmeyen 43 hastanın 12'sinde nedeni bilinmeyen demir eksikliği anemisi vardı ki bu hastaların tümünde sintigrafi negatif olarak sonuçlandı. Yoğun kanama bulguları olan 4 hasta medikal takip sürecinde kaybedildi, geri kalan 27 hastanın kanamaları kendiliğinden ya da konservatif tedavilerle durdu.

\section{SONUÇ}

Çalışmamız aktif GİS kanamalarında kanama odağının belirlenmesinde sintigrafinin primer yöntem olması gerekliliğini göstermektedir. Özellikle ilk 1 saatlik dinamik görüntüleme esnasında saptanan pozitif imajlar, kanama odağ1nın doğru yerinin saptanmasında ve cerrahi gerekliliğin belirlenmesinde yol göstericidir.

Anahtar Sözcükler: Gastrointestinal kanama; işaretli eritrosit sintigrafisi; endoskopik girişimler. ${ }^{2}$ Genel Cerrahi Anabilim Dalı, İstanbul. 
Gastrointestinal hemorrhage is a common indication for hospital admission. While the great majority of the bleedings are observed to be from the upper gastrointestinal system (GIS), about $20 \%$ of them originate from the lower GIS. ${ }^{[1]}$ In the upper GIS bleedings, the source of bleeding can be localized in $80-97 \%$ with endoscopy and $75 \%$ of these will either stop spontaneously or will respond to the medical therapy, while $10 \%$ of them will require urgent operation. ${ }^{[2]}$ In the case of lower GIS bleedings, $80 \%$ will cease spontaneously without further intervention, about $25 \%$ of them will start to bleed again, and about $10-15 \%$ will require urgent operation. ${ }^{[3]}$

It is essential to locate the site of bleeding before any intervention. The current methods for this purpose are endoscopy, angiography, and scintigraphic techniques. Among these, as a major advantage, scintigraphic methods permit the rendering of the visual image of the whole abdomen at the same time. ${ }^{[4]}$ For this reason, some authors advocate the evaluation of patients with scintigraphic methods before undergoing endoscopy or angiography. ${ }^{[3,5-8]}$

The aim of this retrospective study is to report our clinical experience with red blood cell (RBC) scintigraphy and to discuss the role of this method in light of the contemporary literature.

\section{MATERIALS AND METHODS}

Scintigraphic findings of a total of 57 cases $(27 \mathrm{fe}-$ males, 30 males), with a mean age of $43.9 \pm 24$ (1-91) years, who were referred to our clinic between 1995 and 2010 were evaluated retrospectively. The patients who were referred to our clinic had at least one diagnostic examination, such as gastroscopy, colonoscopy or angiography, and the results of the examinations were interpreted as either "normal" or as "no bleeding focus could be found".

Red Blood Cell Labeling Technique: In this study, in vivo and the modified in vitro erythrocyte labeling techniques were used. Briefly, in the in vivo technique, 20 minutes ( $\mathrm{min}$ ) after the injection of stannous agent, 20 millicurie (mCi) (in children $0.2 \mathrm{mCi} / \mathrm{kg}$ ) Tc-99m injection was performed ${ }^{[8]}$ On the other hand, in the modified in vitro technique, $10-15 \mathrm{~min}$ after the injection of stannous agent, 3-5 $\mathrm{ml}$ of blood was drawn from the patient into a heparin-washed injector and transferred to a sterile tube containing $20 \mathrm{mCi}$ (in children $0.2 \mathrm{mCi} / \mathrm{kg}$ ) Tc-99m. The sample was then incubated either at $37^{\circ} \mathrm{C}$ for $10 \mathrm{~min}$ or at room temperature for $20 \mathrm{~min}$ before its reinjection to the patient. ${ }^{[9]}$

Imaging Procedures: The images were obtained by using low-energy all-purpose collimators (ADAC Vertex Plus, Milpitas, CA). The images obtained after the injection were taken from the anterior position in which the camera's area of focus included the entire abdominal region. The images of the first hour were recorded as dynamic images in 60 frames, each with a duration of 60 seconds (s). In the following hours (first 4-6 hours), images were obtained at the beginning of each hour as static images of $300 \mathrm{~s}$. When necessary, a late image was obtained up to the 24th hour.

Interpretation: In the images obtained, the detection of an abnormal activity pattern in the abdominal region was evaluated as positive. Changes in localization of activity in static images were accepted as due to intraintestinal activities. If focal activity remained fixed and did not change in configuration over time, then it was not interpreted as representing a bleeding site. The scintigraphic results as well as endoscopic, colonoscopic, angiographic, and operational findings were evaluated together with the available follow-up of the patients.

\section{RESULTS}

Twenty-three of the patients had a complaint of hematochezia, while 34 complained of melena. The mean hemoglobin level of the patients with GIS bleeding was found to be $7.3 \pm 1.2(4.1-9.6) \mathrm{mg} / \mathrm{dl}$. In their histories, 10 patients were on steroids, 6 were on non-steroid anti-inflammatory drugs, 2 were on acetylsalicylic acid, and 1 patient was on oral anticoagulants. Prior to scintigraphy, gastroscopy in 51 (89.4\%), colonoscopy in $45(78.9 \%)$ and angiography in $9(15.7 \%)$ patients were performed. Of the 57 scintigraphies, $31(54.4 \%)$ were found to be positive, while $26(45.6 \%)$ were found to be negative. Fourteen of 31 patients underwent urgent surgical exploration due to lower GIS bleeding primarily based on the scintigraphic findings. Operational findings of 13 patients confirmed the diagnosis of the scintigraphic findings, giving an accuracy of $92.8 \%$ for the scintigraphic technique. The result of the scintigraphy of one case was interpreted as a bleeding of the small intestine; however, the site of bleeding was found to be her hemorrhoids (Table 1).

Scintigraphies of 19 patients were positive in the 1 st hour dynamic images. Scintigraphies were positive in the initial 1st-4th hour static images in 7 patients and in the 4th-24th hour static images in 5 patients. Of 19 patients with positive scintigraphies within the 1 st hour dynamic images, 10 were operated and 9 were treated medically (Fig. 1).

Unfortunately, 3 patients died after obtaining positive scintigraphic findings. Of the 7 patients with positive scintigraphic findings in the 1st-4th hour static images, 2 were operated and 5 received medical treatment. Two of 5 patients with positive scintigraphic findings in the 4th-24th hour static images were operated, and the remaining 3 patients were treated medi- 
Table 1. Features of patients who underwent surgery for gastrointestinal system bleeding

\begin{tabular}{lclll}
\hline No & Age/Sex & Scan localization & Operation & Pathologic finding \\
\hline 1 & $60 / \mathrm{F}$ & Small intestine & Partial ileal resection & Primary non-Hodgkin lymphoma \\
2 & $62 / \mathrm{M}$ & Small intestine & Partial ileal resection & Metastases of lung carcinoma \\
3 & $34 / \mathrm{M}$ & Rectum & Hemorrhoid & Hyperplastic polyps \\
4 & $42 / \mathrm{F}$ & Small intestine & Internal hemorrhoid & Hyperplastic polyps \\
5 & $63 / \mathrm{M}$ & Diffuse colon & Right hemicolectomy & Hemorrhagic diverticulosis \\
6 & $63 / \mathrm{M}$ & Small intestine & Partial ileal resection & Jejunal diverticulosis \\
7 & $72 / \mathrm{F}$ & Small intestine & Partial ileal resection & Small intestinal segment with focal hemorrhagic necrosis \\
8 & $75 / \mathrm{F}$ & Ascending colon & Right hemicolectomy & Hemorrhagic diverticulosis \\
9 & $10 / \mathrm{F}$ & Small intestine & Diverticulectomy + & \\
& & & Partial ileal resection & Meckel's diverticulum \\
10 & $53 / \mathrm{M}$ & Small intestine & Partial ileal resection & Gastrointestinal stromal tumor \\
11 & $14 / \mathrm{M}$ & Small intestine & Partial ileal resection & Hemangioma \\
12 & $44 / \mathrm{M}$ & Small intestine & Partial ileal resection & Small intestinal segment with focal hemorrhagic necrosis \\
13 & $12 / \mathrm{M}$ & Small intestine & Partial ileal resection & Hemangioma \\
14 & $5 / \mathrm{F}$ & Small intestine & Partial ileal resection & Small intestinal segment with focal hemorrhagic necrosis \\
\hline
\end{tabular}

Table 2. Scintigraphy timing and requirement of urgent surgical exploration

\begin{tabular}{lccc}
\hline & $\begin{array}{c}\text { 1st hour } \\
\text { dynamic images (n) }\end{array}$ & $\begin{array}{c}\text { 1st - 4th hour } \\
\text { static images (n) }\end{array}$ & $\begin{array}{c}\text { 4th - 24th hour } \\
\text { static images (n) }\end{array}$ \\
\hline Requirement of surgical exploration & 10 & 2 & 2 \\
Conservative therapy & $9 *$ & 5 & 3 \\
\hline
\end{tabular}

* Three patients died while under conservative treatment without surgical intervention.

cally (Table 2). As a result, of 31 cases who had positive scintigraphic findings, 14 were operated, and in $13(92.8 \%)$ of the patients, it was noted that the correct foci of the bleeding was determined with RBC scintigraphy. From another aspect, among patients whose sites of bleeding were localized with scintigraphic methods, $48.1 \%$ required surgical intervention (Table 3).
Of the 43 patients who were not operated, 2 patients died due to abundant bleeding, 1 patient died due to pneumonia, and 1 patient who was evaluated as negative died due to hemolytic uremia syndrome. The GIS bleeding of the remaining 39 patients ceased spontaneously or with conservative measures (i.e., blood transfusion, vitamin $\mathrm{K}$ injection, iron supplements, suppositories for internal hemorrhoids).
Fig. 1. A 58-year-old patient was admitted to the emergency room with the complaint of hematochezia. Tc-99m labeled RBC scintigraphy was performed to detect a possible lower gastrointestinal bleeding. In the early dynamic images, bleeding was detected on the right side of the iliac bifurcation (small arrow) with significant increased activity in the following frames (arrow). The localization of the bleeding was interpreted in the region of the small intestine. Based on the scintigraphic findings, the patient was operated. In the surgical exploration, a bleeding jejunal diverticulum was seen and resected, with the confirmation of a negative surgical margin (Table 1, patient number 6).
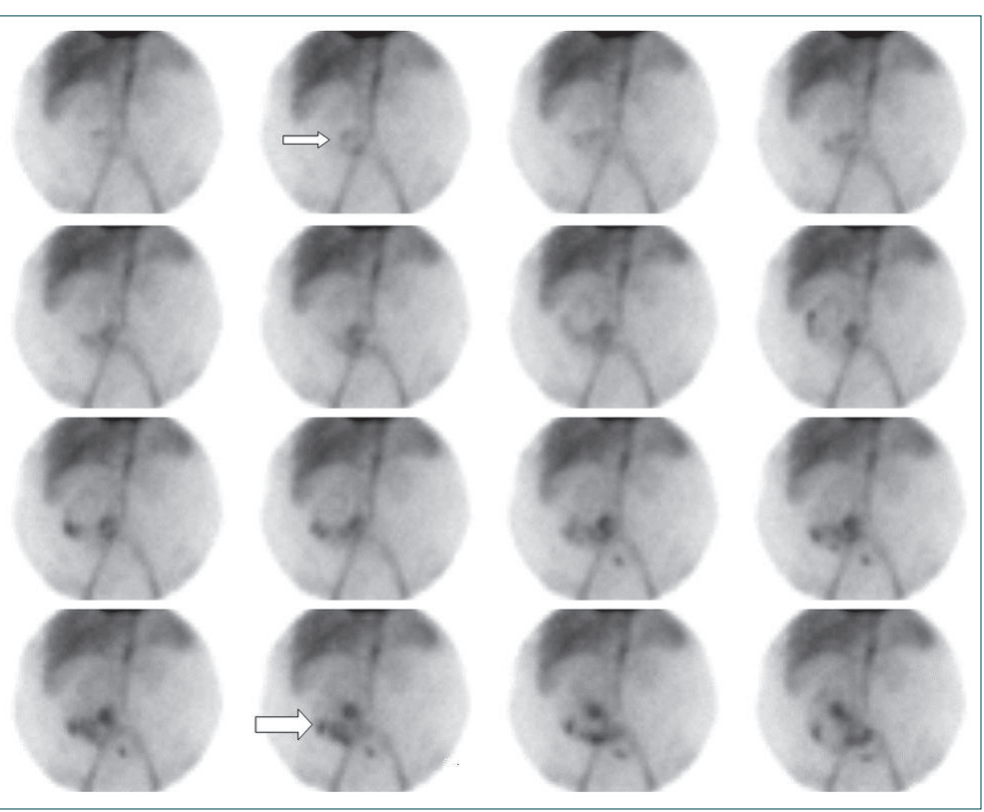
Table 3. Proportion of positive scan results: surgical versus non-operative cases

\begin{tabular}{lccc}
\hline Scan results & $\begin{array}{c}\text { Operative } \\
{[\text { no. }(\%)]}\end{array}$ & $\begin{array}{c}\text { Non-operative } \\
{[\text { no. }(\%)]}\end{array}$ & $\begin{array}{c}\text { \% Requiring } \\
\text { surgery }\end{array}$ \\
\hline Positive / localizing (27) & $13(92.8 \%)$ & $14(32.5 \%)$ & 48.1 \\
Positive / non-localizing (4) & $1(7.2 \%)$ & $3(7 \%)$ & 25 \\
Negative (26) & - & $26(60.5 \%)$ & - \\
Total (57) & $14(100 \%)$ & $43(100 \%)$ & 24.5 \\
\hline
\end{tabular}

\section{DISCUSSION}

In the determination of the localization of bleedings in the GIS, scintigraphic methods have been used over the last 20 years. Some studies have recommended scintigraphic evaluation as the first method to be employed. ${ }^{[3,5-8]}$ In the present study, RBC scintigraphy was not the initial diagnostic method, since all patients had received at least one radiological examination prior to their referral to our clinic. However, no positive result was obtained in any of these examinations for the foci of the bleeding. At this point, the question is whether the scintigraphic techniques for GIS bleeding should be an initial step for the diagnosis or an assisting technique to the other diagnostic tools such as endoscopy and angiography. Although for most centers, RBC scintigraphy is an assisting technique, clinicians should keep in mind that a significant portion of the patients with GIS bleeding are diagnosed with scintigraphy. For this reason, it may be rational to carry this minimally invasive technique to one of the first steps of the algorithm for the management of a bleeding patient.

In the literature, the ratio of detection of lower GIS bleedings with scintigraphy has been reported as between $75-92 \% \cdot{ }^{[6]}$ In our study, 31 of the 57 patients $(54.3 \%)$ with GIS bleedings were found to be positive with scintigraphy. Gunderman et al. ${ }^{[10]}$ reported that, of the 249 cases evaluated with GIS bleeding scans, $115(51.3 \%)$ were found to be positive, and of them, 37 positive cases underwent surgical exploration. In 36 patients $(97.3 \%)$, an accurate bleeding localization was determined through scintigraphy. The requirement for surgical treatment was determined to be 5 times greater for the patients who were positive on scintigraphic evaluation. In our study, of the 31 cases with positive scintigraphic findings, 14 were operated, and in $13(92.8 \%)$ of them, it was noted that the correct foci of the bleeding was determined with RBC scintigraphy. From another aspect, among patients whose sites of bleeding were localized with scintigraphic methods, $48.1 \%$ required surgical intervention.

Many investigators claim that the first method of choice in the determination of lower GIS bleedings should be colonoscopy, since it facilitates not only the diagnosis but also effective treatments with electrocautery and similar interventions. ${ }^{[11,12]}$ However, in acute bleedings requiring urgent management, since colon cleaning cannot be done, colonoscopy may not localize the focus of the bleeding. Vernava et al. ${ }^{[13]}$ reported the ratio of determining the localization of bleeding in patients with severe hematochezia as between $74-82 \%$. In the present study, of 51 and 45 patients with initial gastroscopic and colonoscopic evaluations, respectively, who were referred to our department, none had a demonstrable bleeding site with these techniques.

Mesenteric angiography is capable of providing high resolution images and showing the vascular anatomy in the definitive localization of the focus point of the bleeding, and hence is far superior to scintigraphy. During the procedure, therapeutic interventions can also be done. While bleedings over $0.05 \mathrm{ml} / \mathrm{min}$ can be determined with scintigraphic methods, bleedings over $0.5 \mathrm{ml} / \mathrm{min}$ can be determined with angiography. ${ }^{[14,15]}$ Therefore, if the scintigraphy proves to be negative, there is no practical benefit in performing an angiography. ${ }^{[16-18]}$ In addition, RBC scintigraphy may be helpful in establishing the correct timing of the angiography. ${ }^{[19]}$ In the present study, angiography was performed in nine patients with negative results before referral to our center. In all of these patients, RBC scintigraphies were found to be positive, and three patients underwent surgical exploration. Conservative measures were applied in the remaining patients.

Endoscopy and angiography are generally unsuccessful for demonstrating intermittent bleedings. However, scintigraphy is quiet helpful due to its ability to demonstrate intermittent bleedings. Moreover, compared with the above-mentioned diagnostic methods, scintigraphy has the advantage of high tolerability due to its minimally invasive nature. $2-3 \mathrm{ml}$ of extravasated blood is sufficient for detection. ${ }^{[20,21]}$ Another advantage brought about by this technique is the capability of long-term imaging (up to 24 hours) due to circulation of radioactively marked erythrocytes in the blood pool. ${ }^{[22-24]}$

Timing for scintigraphy is important for determining bleeding localization correctly. Ten of 19 (52.6\%) patients with positive scintigrams in the first hour underwent surgical exploration. In all patients, bleeding sites had been demonstrated with scintigraphic meth- 
ods accurately. The single case of an incorrect positive scan, in which an internal hemorrhoid was interpreted as a small intestine bleeding, was observed in the 4th-24th hour static images. In addition, other nonlocalizing scans were found in the same time interval. Although Jacobson et al. ${ }^{[25]}$ reported that patients with late positive scans had a higher rate of surgery than late negative patients, according to the present study, a positive dynamic image obtained within the first hour is a mainstay for accurate localization of the bleeding and higher rate of requirement of surgery.

The use of RBC scintigraphy as a tool for risk stratification may assist an algorithmic approach to management and may also help to prevent an overaggressive surgical approach to management, which may reduce both morbidity and mortality. ${ }^{[19]} \mathrm{A}$ negative scintigraphic study is predictive of a good outcome and may be a very useful means of risk stratification in patients who do not need to be put at an unnecessary risk of emergency surgery. ${ }^{[26]}$ Consistent with the above-mentioned opinion, in the present study, no patient with negative RBC scintigraphy underwent urgent surgical exploration.

Schillaci et al. ${ }^{[27]}$ performed a study with Tc-99m RBC scintigraphy using a single- photon emission computed tomography (SPECT)/CT hybrid imaging system in patients with lower GI bleeding. This system was used only for patients with positive planar scintigraphy and the authors found that SPECT/CT images may yield a better localization of GI bleeding in comparison with the standard planar scan.

Glucagon can be used in conjunction with RBC scintigraphy for improving detection and localization of the bleeding site. Further, the use of subtraction scintigraphy during $\mathrm{RBC}$ imaging may improve the contrast. ${ }^{[28]}$

In conclusion, the present study addresses the importance of RBC scintigraphy in determination of the correct localization of GIS bleedings. For this reason, RBC scintigraphy could be the primary tool for the diagnosis of patients with GIS bleeding, especially in centers without immediate availability to angiographic intervention. Moreover, positive dynamic images obtained within the first hours of the imaging are probably more accurate for demonstrating the bleeding localization and are a good predictor of the requirement of surgical exploration.

\section{REFERENCES}

1. Friedman LS, Martin P. The problem of gastrointestinal bleeding. Gastroenterol Clin North Am 1993;22:717-21.

2. Fuad H, Sleiman N, Al-Enizi E. Gastrointestinal bleeding. In: Elgazzar A, editor. The pathophysiologic basis of nuclear medicine. Berlin: Springer Verlag; 2001. p. 289-290.

3. Al Qahtani AR, Satin R, Stern J, Gordon PH. Investiga- tive modalities for massive lower gastrointestinal bleeding. World J Surg 2002;26:620-5.

4. Alavi A, Worsley D, Zhuang H. Scintigraphic detection and localization of gastrointestinal bleeding sites. In: Sandler MP, editor. Diagnostic nuclear medicine. 4th ed., Philadelphia: Lippincott Williams \& Wilkins; 2003. p. 531-51.

5. Winzelberg GG, McKusick KA, Froelich JW, Callahan RJ, Strauss HW. Detection of gastrointestinal bleeding with $99 \mathrm{mTc}-$ labeled red blood cells. Semin Nucl Med 1982;12:139-46.

6. Orecchia PM, Hensley EK, McDonald PT, Lull RJ. Localization of lower gastrointestinal hemorrhage. Experience with red blood cells labeled in vitro with technetium Tc 99m. Arch Surg 1985;120:621-4.

7. Treves ST, Grand RJ. Gastrointestinal bleeding. In: Treves ST, editor. Pediatric nuclear medicine. 2nd ed., New York: Springer-Verlag; 1994. p. 453-462.

8. Kostamo KL. Evaluation of gastrointestinal bleeding by nuclear medicine techniques. In: Henkin RE, Boles MA, Dillehay GL, editors. Nuclear medicine. Vol II, St. Louis: Mosby, Inc., 1996. p. 1016-1022.

9. Suzman MS, Talmor M, Jennis R, Binkert B, Barie PS. Accurate localization and surgical management of active lower gastrointestinal hemorrhage with technetium-labeled erythrocyte scintigraphy. Ann Surg 1996;224:29-36.

10. Gunderman R, Leef J, Ong K, Reba R, Metz C. Scintigraphic screening prior to visceral arteriography in acute lower gastrointestinal bleeding. J Nucl Med 1998;39:1081-3.

11. Richter JM, Christensen MR, Kaplan LM, Nishioka NS. Effectiveness of current technology in the diagnosis and management of lower gastrointestinal hemorrhage. Gastrointest Endosc 1995;41:93-8.

12. Chaudhry V, Hyser MJ, Gracias VH, Gau FC. Colonoscopy: the initial test for acute lower gastrointestinal bleeding. Am Surg 1998;64:723-8.

13. Vernava AM 3rd, Moore BA, Longo WE, Johnson FE. Lower gastrointestinal bleeding. Dis Colon Rectum 1997;40:84658.

14. Tada M, Shimizu S, Kawai K. Emergency colonoscopy for the diagnosis of lower intestinal bleeding. Gastroenterol Jpn 1991;26:121-4.

15. Fiorito JJ, Brandt LJ, Kozicky O, Grosman IM, Sprayragen $\mathrm{S}$. The diagnostic yield of superior mesenteric angiography: correlation with the pattern of gastrointestinal bleeding. Am J Gastroenterol 1989;84:878-81.

16. Nicholson ML, Neoptolemos JP, Sharp JF, Watkin EM, Fossard DP. Localization of lower gastrointestinal bleeding using in vivo technetium-99m-labelled red blood cell scintigraphy. Br J Surg 1989;76:358-61.

17.Zuckerman GR, Prakash C. Acute lower intestinal bleeding: part I: clinical presentation and diagnosis. Gastrointest Endosc 1998;48:606-17.

18. Baum S. Angiography and the gastrointestinal bleeder. Radiology 1982;143:569-72.

19. Howarth DM. The role of nuclear medicine in the detection of acute gastrointestinal bleeding. Semin Nucl Med 2006;36:133-46.

20. Thrall JH, Ziessman HA. Gastrointestinal system. In: Thrall JH, Ziessman HA, editors. Nuclear medicine. The Requisites. 2nd ed., St Louis: Mosby, Inc., 2001. p. 280-91.

21. Hoedema RE, Luchtefeld MA. The management of lower gastrointestinal hemorrhage. Dis Colon Rectum 2005;48:201024. 
22. Winzelberg GG, Froelich JW, McKusick KA, Waltman AC, Greenfield AJ, Athanasoulis CA, et al. Radionuclide localization of lower gastrointestinal hemorrhage. Radiology 1981;139:465-9.

23. Ponzo F, Zhuang H, Liu FM, Lacorte LB, Moussavian B, Wang S, et al. Tc-99m sulfur colloid and Tc-99m tagged red blood cell methods are comparable for detecting lower gastrointestinal bleeding in clinical practice. Clin Nucl Med 2002;27:405-9.

24. Nwakanma L, Meyerrose G, Kennedy S, Rakvit A, Bohannon T, Silva M. Recurrent gastrointestinal bleeding diagnosed by delayed scintigraphy with Tc-99m-labeled red blood cells. Clin Nucl Med 2003;28:691-3.

25. Jacobson AF, Cerqueira MD. Prognostic significance of late imaging results in technetium-99m-labeled red blood cell gastrointestinal bleeding studies with early negative images. J Nucl Med 1992;33:202-7.

26. Zettinig G, Staudenherz A, Leitha T. The importance of delayed images in gastrointestinal bleeding scintigraphy. Nucl Med Commun 2002;23:803-8.

27. Schillaci O, Spanu A, Tagliabue L, Filippi L, Danieli R, Palumbo B, et al. SPECT/CT with a hybrid imaging system in the study of lower gastrointestinal bleeding with technetium-99m red blood cells. Q J Nucl Med Mol Imaging 2009;53:281-9.

28. Currie GM, Kiat H, Wheat JM. Scintigraphic evaluation of acute lower gastrointestinal hemorrhage: current status and future directions. J Clin Gastroenterol 2011;45:92-9. 